DOI https://doi.org/10.18551/rjoas.2017-11.15

\title{
ANALYSIS OF RISK DETERMINATION IN INTERNAL AUDIT PLANNING IN MICRO BANKING OF PT.BANK DANAMON
}

\author{
Widjaja Henry*, Ruslim Herman \\ Post Graduate Program, Tarumanegara University, Jakarta, Indonesia \\ *E-mail: henry.widjaja.sjb@gmail.com
}

\begin{abstract}
This research intends to examine risk assessment system at each branch of micro credit of BDI Bank, so that strategy to be conducted in this research are: 1) Internal Audit strategy in detecting risks that may affect the performance of Danamon Bank micro credit branches; 2) reviews the risk assessment system for each of Danamon Bank's micro branches. This study uses Analytic Hierarchy Process (AHP) method which aims to determine risk assessment and ranking of micro bank branches that will influence the decision in determining the micro branch that will be audited. The processing results show that from 100 sample data using AHP, it is obtained 10 branches that have high risk, 56 branches that have medium risk, and 34 branches that have low risk. After the risk assessment results for each branch have been determined, then the Auditor can perform the audit planning. For branches with high and medium risk, the Auditor must audit it every year. For low-risk branches, the Auditor may perform several samples to exercise control and every four years, the Auditor must audit it.
\end{abstract}

\section{KEY WORDS}

Analytic hierarchy process, internal audit, micro banking.

Financial Institutions may be in the form of Commercial Bank, Credit Bank and Sharia Bank. Besides bank, other financial institutions may be in the form of Savings and Loans Cooperatives, Insurance and Securities. All financial institutions have their business activities which are always faced with risks, including: risk of credit, operational, market, liquidity, compliance, reputation, legal and strategic. Definition of risk is a condition that can hinder the purpose of a business (Supono, 2007). Danamon Bank is one of the commercial banks that has several kinds of credit products such as working capital loans, investments, consumptive, credit cards, etc. Micro credit is one of Danamon Bank 's business with more than 600 branches spread all over Indonesia. Given the importance of supervisory function, it is necessary to have a risk assessment system in each branch. A risk assessment system for microcredit branches will assist in the determination of future audit plans more precisely. Audit is a process of evaluation and accumulation of evidence about various information to determine and report the level of relationship between information obtained with certain criteria (Arens, 2008). Improper risk assessment may cause high risk branches not to be a priority in auditing and may cause harm to the Bank.

This research intends to examine risk assessment system in each branch of micro credit of BDI Bank, so that the strategies that will be conducted in this research are: 1) Internal Audit strategy in detecting risks that may affect the performance of Danamon Bank micro credit branch 2) reviews the risk assessment system for each of Danamon Bank's micro branches. Internal Audit of Danamon Bank needs to make strategic changes by applying a Risk Based Audit approach in conducting examination tasks. Risk Based Audit is an audit approach that has been developed since 2000 and is currently widely used by internal audit institutions in some organizations because this approach is in line with the development of Internal Audit functions to be effectively able to provide value added, especially for related matters with the organization's internal control (trusted advisor).

A risk-based audit approach should be able to provide assurance that business risks have been identified, evaluated, and monitored on an ongoing basis (Andreas et al, 2008). Internal control systems and monitoring activities by management of internal controls have 
been well designed and operate effectively, efficiently, and economically in managing those risks in accordance with directives granted (or approved) by the board of directors. The role of Internal Audit in a bank is necessary to minimize the risks that exist in this industry, so the existence of Internal Audit can improve bank performance in achieving the goal. According to the Institute of Internal Auditors (IIA), internal audit is an independent, objective assurance and consulting activity designed to add value and improve an organization's operations. It helps an organization accomplish its objectives by bringing a systematic, disciplined approach to evaluate and improve the effectiveness of risk management, control, and governance processes (The Institute of Internal Auditors). In Academic literature in Indonesia (Mulyadi, 2002), the meaning of Internal Audit itself is the employee who is assigned as Auditor to check whether the rules and policies determined by the bank in maintaining business assets have been implemented in accordance with the rules. The current audit activities are not just financial audits of financial audit and compliance audit, but the focus of attention is on all aspects that affect the company's performance and management control as well as the risk aspects of management and internal control (Buana, 2009).

Given that Danamon Bank micro banking operates in more than 600 branches, it is necessary to have a system that can determine the level of risk in each branch. This level of risk per branch (Macro Risk) will assist audit management in the preparation of audit plans that are generally related to the adequacy of human resources, audit time, and audit costs. Risk Based Audit System with macro risk approach for new micro credit branches was developed at Danamon Bank in 2015 and the system was then socialized and implemented to internal audit units at headquarters and region. The success of the Risk Based Audit system with the determination of risk per branch (macro risk) cannot be separated from several times of trial and verification conducted by comparing the level of risk per branch with audit results conducted by the auditor.

Business Strategy and Segmentation. Danamon Bank combines the ability to offer services and products that meet the needs of each segment by ensuring that every customer's needs are met well while considering all potential risks. Business strategy and business segmentation shows that Danamon Bank makes micro banking consisting of Mass Self-Employed and Mass Employed products as one of the foundations in business/commercial product strategy and consumer products.

Corporate Risk Management. Danamon Bank uses eight risk categories in accordance with Bank of Indonesia's regulation, eight risk categories determined by Bank of Indonesia are: credit, market, liquidity, operational, strategic, reputation, law and compliance. Danamon Bank also implements Three Lines of Defense in its risk management and control framework concept. First Line of Defense is a line of business that will identify, control, and reduce risks in its own business. Second Line of Defense is the risk management division. Third Line of Defense is the Internal Audit Unit that conducts the examination and testing of the effectiveness of the risk implementation and control management.

Company's Performance. The financial performances of Danamon Bank for the budget year of 2016, based on the annual consolidated financial statements that have been audited are:

1. Total bank assets as of December 2016 is IDR 174 trillion with earning assets of IDR 166 trillion (95\%).

2. The loan portfolio granted as of December 31,2016 is IDR 126 trillion with mass market loan composition such as micro loan, two-wheeled motor vehicle loan, unsecured personal loan, reaching to IDR 45 trillion.

3. Non-Performing Loan (NPL) of Danamon bank is IDR 3.7 trillion or $3.1 \%$ of the total loan provided by the bank.

4. Bank operating income during 2016 was IDR 4.9 trillion (grew $26 \%$ compared to 2015) with net profit of IDR 2.8 trillion (12\% growth compared to 2015)

5. Capital Adequacy Ratio (CAR) is $20.9 \%$ and Return on Average Equity (ROAE) is at the level of $8 \%$.

Details of Danamon Bank's financial performance and financial ratios can be seen in the table below. 
Table 1 - Danamon Bank's Financial Performance in 2016

\begin{tabular}{|l|c|}
\hline \multicolumn{1}{|c|}{ In billions of Rupiah except share data } & 2016 \\
\hline \multicolumn{1}{|c|}{ CONSOLIDATION BALANCE } & 174.087 \\
\hline Asset & 166.651 \\
\hline Productive Asset-bruto ${ }^{\text {a) }}$ & 122.385 \\
\hline Credit Provided-bruto ${ }^{\text {(1) }}$ & 3.743 \\
\hline Loans in Problem & 17.446 \\
\hline Effects - bruto & 9.563 \\
\hline Government's Obligation & 106.612 \\
\hline Savings & 113.890 \\
\hline Amount of Funding & 137.709 \\
\hline Amount of Liabilities & 36.378 \\
\hline Equity and Controller Interest & 165 \\
\hline Inclusion - Net & 9.584 .643 .365 \\
\hline Number of Shares Paid and Fully Paid (in unit) & 20.665 \\
\hline \multicolumn{2}{|c|}{ REPORT OF CONSOLIDATED STATEMENTS OF INCOME } \\
\hline Interest Income & 6.876 \\
\hline Interest Expense & 14.400 \\
\hline Interest Income and Net Underwriting & 4.071 \\
\hline Other Operational Income & 3.020 \\
\hline General Expense and Administration & 4.879 \\
\hline Manpower Expense and Allowance & 4.441 \\
\hline Report of Impairment Loss & 4.934 \\
\hline Operational Income - Net & 541 \\
\hline Non-operational Expense (Income) - Net & 4.393 \\
\hline Profit Right & 1.600 \\
\hline Income Tax Expense & 2.793 \\
\hline Net Profit &
\end{tabular}

Source: www.idx.co.id - The Annual Financial Statement of Listed Company (BDMN).

Table 2 - Danamon Bank's Financial Ratios in 2016

\begin{tabular}{|c|c|}
\hline (In billions of Rupiah except share data) & 2016 \\
\hline \multicolumn{2}{|l|}{ KEY FINANCIAL RATIOS (\%) } \\
\hline \multicolumn{2}{|l|}{ I. Capital } \\
\hline 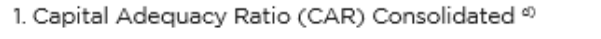 & 20.9 \\
\hline Tier I & 20.1 \\
\hline Tier II & 0.8 \\
\hline 2. Assets to Equity & 4.8 \\
\hline \multicolumn{2}{|l|}{ II. Earning Assets } \\
\hline $\begin{array}{l}\text { 1. Non Performing Earning } \\
\text { Assets and Non Productive } \\
\text { Assets to Total Earnings } \\
\text { and Non Productive Assets }\end{array}$ & 1.9 \\
\hline $\begin{array}{l}\text { 2. Non Performing Earning Assets to Total Productive } \\
\text { Assets }\end{array}$ & 2.4 \\
\hline 3. Non Performing Loans (NPL) to Total Loans-Gross & 3.1 \\
\hline 4. Non Performing Loan (NPL) to Total Loans-Net & 1.8 \\
\hline $\begin{array}{l}\text { 5. Allowance for Impairment Losses for Financial Assets } \\
\text { to Productive Assets *) }\end{array}$ & 3.0 \\
\hline 6. Loan Loss Coverage & 116.9 \\
\hline \multicolumn{2}{|l|}{ III. Rentability } \\
\hline 1. Return on Average Assets (ROAA) & 2.5 \\
\hline 2. Return on Average Equity (ROAE) & 8.0 \\
\hline 3. Debt to Assets & 0.79 \\
\hline 4. Debt to Equity & 3.79 \\
\hline 5. Net Interest Margin (NIM) & 8.9 \\
\hline 6. Cost to Income & 48.8 \\
\hline 7. Fee Income & 22.1 \\
\hline 8. Operating Expense to Operating Income & 77.3 \\
\hline 9. Cost of Funds & 5.1 \\
\hline
\end{tabular}

Source: www.idx.co.id - The Annual Financial Statement of Listed Company (BDMN). 


\section{METHODS OF RESEARCH}

This study uses the Analytic Hierarchy Process (AHP) method which aims to determine risk assessment and ranking of micro bank branches that will influence the decision in determining the micro branch that will be audited, (Saaty, 2000). The end result of AHP will determine the rank or vector priority of each branch. This study uses AHP model formulation to assess the risk of Danamon Bank micro branches that generate risk ranking in each branch. The AHP model basically has three steps, namely hierarchy formation, assessment, and priority vectors, (Saaty, 2013). The stages of this research include:

Data collection of 15 risk factors that have a level of risk. The beginning of this research will perform the data collection needed for the calculation of 15 risk factors that already have a risk level. Data has been processed by Analytic Internal Audit division every month. This research will use data of August 2015 until March 29th, 2017.

The Formation of Hierarchy. The formation of Hierarchy in the Analytic Hierarchy Process (AHP) model begins with the determination of the objectives of this research problem. This research will use AHP model with 4 level hierarchies as follows:

1. Level 1 - The target of the decision that will be taken is placed at the top of the hierarchy.

2. Level 2 - Assessment criteria that can indicate the quality or level of risk factors of the alternative model used.

3. Level 3 - Assessment sub-criteria that can indicate the quality or level of risk factors of the alternative model used in level 2 criteria.

4. Level 4 - Branches assessed at risk level that may indicate quality or risk level.

Paired Matrix Formation (Criteria, Sub-criteria, and Branches). The formation of a pair matrix can be done by order according to the number of pairs in each group. Pair weight assessment can be incorporated into the cells above. The diagonal cell will be entered with the number 1 . The other cell will be filled with the number corresponding to the division of the weight of the pair and on the opposite cell, it will be filled with the opposite number (eg, may=yam). Distribution of the weight of the spouse can be done each order and each group.

Formation of Inter-paired Normalization (Criteria, Sub-criteria and Branches). Formation of normalization is done after making the formation of matrix pair between data done in each group, to get normalization by counting data per cell divided by amount of data per group vertically.

$$
\text { Normalization Data } 1=\frac{\text { Cell } 1}{\text { Total Number of Column } 1}
$$

The above calculation may be repeated for all data and calculations are performed for the pair between criteria, sub-criteria, and branches.

Formation of Inter-paired Priority Vector (Criteria, Sub-criteria, and Branches). The formation of priority vectors is done after the normalization of pairs between the data functions to obtain a priority vector by calculating the total amount of data as $\mathrm{N}$ and multiplied by the total normalization.

$$
\text { Inter Data VP } 1=1 / N \times \text { sum (Normalization Data 1) }
$$

The above calculation may be repeated for all data and calculations are performed for the pair between criteria, sub-criteria, and branches.

Calculation of Each Branch Priority Vector Total. Determining Total of Priority Vector is done by calculating priority vectors of criteria, sub-criteria, and branches as shown in the following equation. Total Branch $1=(V P$ Criteria $1 \times$ VP Sub Criteria $1 \times$ VP Branch 1$)+\ldots+($ VP Criteria N $x$ VP Sub
Criteria Nx VP Branch N) 
Once the total priority vector for each branch has been calculated, the branch rank can be determined from the branch with the highest priority total vector until the branch has the lowest total vector priority. Branches that have the highest priority vector total are the highest-risk branches and the branches which have the lowest total vector total are the lowest-risk branches.

Calculating Consistency Ratio (CR). Consistency Ratio is calculated by dividing the Consistency Index $(\mathrm{Cl})$ with Random Index $(\mathrm{RI})$. The Consistency Index $(\mathrm{Cl})$ is obtained from the average priority vector value $(\lambda)$ divided by the number of alternatives/types of risks used (n).

$$
C I=\frac{\lambda-n}{n-1} C R=\frac{C I}{R I}
$$

Random Index (RI) for matrix with order $10 \times 10$ is 1.49 .

Formation of Risk Level Scoring. Forming a risk-level scoring is by finding the maximum and minimum total vector priorities to gain distance at each risk level. In the formation of risk level scoring, it will be divided into 3 levels, namely High Risk, Medium Risk, and Low Risk.

\section{RESULTS AND DISCUSSION}

Branch Assessment Results Using AHP. Analytic Hierarchy Process (AHP) used in this study aims to determine the risk assessment and ranking of Danamon Bank micro branches that will influence the decision in determining the micro branches that will be audited. The end result of AHP will determine the rank or vector priority of each branch. This study uses AHP model formulation to assess the risk of Danamon Bank micro branches that generate risk ranking in each branch. The AHP model basically has three steps, namely formation of hierarchy, assessment, and priority vectors.

Hierarchical Formation Analysis Results. Hierarchical formation is a conceptual approach for rating ranking models using the AHP model. The AHP model used in this study has 4 hierarchical levels:

1. Level I: The top of the hierarchy is placed for the target of the decision that will be taken. The purpose of this study is to assess risk in micro branch at Danamon Bank to obtain risk ranking for each branch.

2. Level II: The second level is used for the criteria to assess the risk on the microbranch and to rank risk on each branch. The criteria used are: Unsecured, Top Up, New NOA, Restructure, FID Flow Rate, Unsec OS Per Tot OS, Last OS, NPL WO $6 M$, Flow Rate, Unrecovery Rate.

3. Level III: The third level is used for sub-criteria of criteria at level II that can assist in risk assessment of microcredit in more detail.Subcriteria used in the study are:

- Unsecured has sub criteria DPD 30 Unsec and OS Unsec Last 1Y;

- Top Up has sub criteria New NOA Top Up per Tot NOA and DPD 30 Top Up;

- New NOA has sub criteria New NOA $1 Y$ and New NOA 6M;

- Restructure has sub criteria Amt Rest Last 1Y and DPD 30Rest;

- FID Flow Rate has sub criteria FID and Flow Rate 30+.

4. Level IV: The fourth level is used for risk assessment on the micro banking branch to determine the risk rankings on the branch.

Results of Score Formation/Weight of Risk Factors. Risk factors along with their weight that have been determined by the auditor can be formed as a matrix. Matrix is formed according to each hierarchy and order group according to the number of risk factors or branches of each hierarchy group. Assessment of specified weights can be entered according to existing cells, for each cell, it can be filled in accordance with its partner in accordance with the row and column of the score $\left(\mathrm{eg} \frac{\text { row weight }}{\text { column weight }}=\frac{6}{6}=1\right)$. 
Results of Paired Matrix Inter Criteria. Intercriteria Matrix is $10 \times 10$ ordered matrix formed from risk factors and matrix formation results that can be seen in the table below:

Table 3 - Paired Matrix Inter Criteria

\begin{tabular}{|c|c|c|c|c|c|c|c|c|c|c|c|}
\hline & & UNSECURED & TOPUP & $\begin{array}{l}\text { NEW } \\
\text { NOA }\end{array}$ & RESTRUCTURE & $\begin{array}{c}\text { FID } \\
\text { FLOWRATE }\end{array}$ & $\begin{array}{c}\text { OS UNSEC } \\
\text { PER TOT OS }\end{array}$ & LASTOS & $\begin{array}{c}\text { NPL WO } \\
6 \mathrm{M}\end{array}$ & FLOWRATE & $\begin{array}{c}\text { UNRECOVERY } \\
\text { RATE }\end{array}$ \\
\hline & Weight & 6 & 4 & 4 & 1 & 9 & 4 & 3 & 6 & 3 & 2 \\
\hline UNSECURED & 6 & 1.0000 & 1.5000 & 1.5000 & 6.0000 & 0.6667 & 1.5000 & 2.0000 & 1.0000 & 2.0000 & 3.0000 \\
\hline TOPUP & 4 & 0.6667 & 1.0000 & 1.0000 & 4.0000 & 0.4444 & 1.0000 & 1.3333 & 0.6667 & 1.3333 & 2.0000 \\
\hline NEW NOA & 4 & 0.6667 & 1.0000 & 1.0000 & 4.0000 & 0.4444 & 1.0000 & 1.3333 & 0.6667 & 1.3333 & 2.0000 \\
\hline RESTRUCTURE & 1 & 0.1667 & 0.2500 & 0.2500 & 1.0000 & 0.1111 & 0.2500 & 0.3333 & 0.1667 & 0.3333 & 0.5000 \\
\hline FID FLOWRATE & 9 & 1.5000 & 2.2500 & 2.2500 & 9.0000 & 1.0000 & 3.0000 & 3.0000 & 1.5000 & 3.0000 & 4.5000 \\
\hline OS UNSEC PER TOT OS & 4 & 0.6667 & 1.0000 & 1.0000 & 4.0000 & 0.3333 & 1.0000 & 1.3333 & 0.6667 & 1.3333 & 2.0000 \\
\hline LASTOS & 3 & 0.5000 & 0.7500 & 0.7500 & 3.0000 & 0.3333 & 0.7500 & 1.0000 & 0.5000 & 1.0000 & 1.5000 \\
\hline NPLW06M & 6 & 1.0000 & 1.5000 & 1.5000 & 6.0000 & 0.6667 & 1.5000 & 2.0000 & 1.0000 & 2.0000 & 3.0000 \\
\hline FLOWRATE & 3 & 0.5000 & 0.7500 & 0.7500 & 3.0000 & 0.3333 & 0.7500 & 1.0000 & 0.5000 & 1.0000 & 1.5000 \\
\hline \multirow[t]{2}{*}{ UNRECOVERY RATE } & 2 & 0.3333 & 0.5000 & 0.5000 & 2.0000 & 0.2222 & 0.5000 & 0.6667 & 0.3333 & 0.6667 & 1.0000 \\
\hline & SUM & 7.0000 & 10.5000 & 10.5000 & 42.0000 & 4.5556 & 11.2500 & 14.0000 & 7.0000 & 14.0000 & 21.0000 \\
\hline
\end{tabular}

Source: Macro risk assessment Audit Analytic - Danamon Bank' Internal Audit Unit as of 31 March 2017.

Results of Paired Matrix Inter Sub-criteria. Intercity Matrix for Unsecured Matrix is 2x2 ordered matrix formed from risk factors that support the criteria factor on the criteria and the result of matrix formation can be seen in the table below:

Table 4 - Paired Matrix of Inter Unsecured Sub-criteria

\begin{tabular}{|c|c|c|c|}
\hline & & DPD30UNSEC & OSUNSECLAST1Y \\
\cline { 2 - 4 } & Weight & $\mathbf{3}$ & $\mathbf{2}$ \\
\hline DPD30UNSEC & 3 & 1.0000 & 1.5000 \\
\hline OSUNSECLAST1Y & 2 & 0.6667 & 1.0000 \\
\hline & SUM & 1.6667 & 2.5000 \\
\cline { 2 - 4 }
\end{tabular}

Source: Macro risk assessment Audit Analytic - Danamon Bank Internal Audit Unit as of 31 March 2017.

Results of Inter-branch Matrix. Inter-branch matrix for FID is a matrix of $10 \times 10$ formed from the branch. The results of matrix formation can be seen in the table below:

Table 5 - Paired Matrix of FID Inter Unsecured Sub-criteria

\begin{tabular}{|c|c|c|c|c|c|c|c|c|c|c|c|}
\hline & & Branch 1 & Branch 2 & Branch 3 & Branch 4 & Branch 5 & Branch 6 & Branch 7 & Branch 8 & Branch 9 & Branch 10 \\
\hline & Weight & 5 & 5 & 2 & 4 & 2 & 4 & 1 & 1 & 1 & 1 \\
\hline Branch 1 & 5 & 1.0000 & 1.0000 & 2.5000 & 1.2500 & 2.5000 & 1.2500 & 5.0000 & 5.0000 & 5.0000 & 5.0000 \\
\hline Branch 2 & 5 & 1.0000 & 1.0000 & 2.5000 & 1.2500 & 2.5000 & 1.2500 & 5.0000 & 5.0000 & 5.0000 & 5.0000 \\
\hline Branch 3 & 2 & 0.4000 & 0.4000 & 1.0000 & 0.5000 & 1.0000 & 0.5000 & 2.0000 & 2.0000 & 2.0000 & 2.0000 \\
\hline Branch 4 & 4 & 0.8000 & 0.8000 & 2.0000 & 1.0000 & 2.0000 & 1.0000 & 4.0000 & 4.0000 & 4.0000 & 4.0000 \\
\hline Branch 5 & 2 & 0.4000 & 0.4000 & 1.0000 & 0.5000 & 1.0000 & 0.5000 & 2.0000 & 2.0000 & 2.0000 & 2.0000 \\
\hline Branch 6 & 4 & 0.8000 & 0.8000 & 2.0000 & 1.0000 & 2.0000 & 1.0000 & 4.0000 & 4.0000 & 4.0000 & 4.0000 \\
\hline Branch 7 & 1 & 0.2000 & 0.2000 & 0.5000 & 0.2500 & 0.5000 & 0.2500 & 1.0000 & 1.0000 & 1.0000 & 1.0000 \\
\hline Branch 8 & 1 & 0.2000 & 0.2000 & 0.5000 & 0.2500 & 0.5000 & 0.2500 & 1.0000 & 1.0000 & 1.0000 & 1.0000 \\
\hline Branch 9 & 1 & 0.2000 & 0.2000 & 0.5000 & 0.2500 & 0.5000 & 0.2500 & 1.0000 & 1.0000 & 1.0000 & 1.0000 \\
\hline Branch 10 & 1 & 0.2000 & 0.2000 & 0.5000 & 0.2500 & 0.5000 & 0.2500 & 1.0000 & 1.0000 & 1.0000 & 1.0000 \\
\hline & SUM & 5.2000 & 5.2000 & 13.0000 & 6.5000 & 13.0000 & 6.5000 & 26.0000 & 26.0000 & 26.0000 & 26.0000 \\
\hline
\end{tabular}

Source: Macro risk assessment Audit Analytic - Bank Danamon Internal Audit Unit as of 31March 2017.

Weight Result of Priority Vector. The formation of the priority vector weights on the AHP method for each factor in the matrix is intended to allow the weight of each factor that will be expressed as normalized. This normalized weight is a weight of the relative value for each factor in each column, by comparing each scaled value with the number of columns.

Weight Result of Inter-Criteria Pair Matrix Priority Vectors. Normalization of pair matrix between criteria is a matrix of $10 \times 10$ formed from risk factor and result of normalization formation of matrix that can be seen in table below. 
Table 6 - Matrix of Paired Normalization between Risk Factors

\begin{tabular}{|c|c|c|c|c|c|c|c|c|c|c|c|}
\hline & & UNSECURED & TOPUP & $\begin{array}{l}\text { NEW } \\
\text { NOA }\end{array}$ & RESTRUCTURE & $\begin{array}{c}\text { FID } \\
\text { FLOWRATE }\end{array}$ & $\begin{array}{l}\text { OS UNSEC } \\
\text { PER TOT OS }\end{array}$ & LAST_OS & $\begin{array}{c}\text { NPL WO } \\
6 \mathrm{M}\end{array}$ & FLOWRATE & $\begin{array}{c}\text { UNRECOVERY } \\
\text { RATE }\end{array}$ \\
\hline & Weight & 6 & 4 & 4 & 1 & 9 & 4 & 3 & 6 & 3 & 2 \\
\hline UNSECURED & 6 & 0.1429 & 0.1429 & 0.1429 & 0.1429 & 0.1463 & 0.1333 & 0.1429 & 0.1429 & 0.1429 & 0.1429 \\
\hline TOPUP & 4 & 0.0952 & 0.0952 & 0.0952 & 0.0952 & 0.0976 & 0.0889 & 0.0952 & 0.0952 & 0.0952 & 0.0952 \\
\hline NEW NOA & 4 & 0.0952 & 0.0952 & 0.0952 & 0.0952 & 0.0976 & 0.0889 & 0.0952 & 0.0952 & 0.0952 & 0.0952 \\
\hline RESTRUCTURE & 1 & 0.0238 & 0.0238 & 0.0238 & 0.0238 & 0.0244 & 0.0222 & 0.0238 & 0.0238 & 0.0238 & 0.0238 \\
\hline FID FLOWRATE & 9 & 0.2143 & 0.2143 & 0.2143 & 0.2143 & 0.2195 & 0.2667 & 0.2143 & 0.2143 & 0.2143 & 0.2143 \\
\hline $\begin{array}{l}\text { OS UNSEC PER TOT } \\
\text { OS } \\
\end{array}$ & 4 & 0.0952 & 0.0952 & 0.0952 & 0.0952 & 0.0732 & 0.0889 & 0.0952 & 0.0952 & 0.0952 & 0.0952 \\
\hline LASTOS & 3 & 0.0714 & 0.0714 & 0.0714 & 0.0714 & 0.0732 & 0.0667 & 0.0714 & 0.0714 & 0.0714 & 0.0714 \\
\hline NPLW06M & 6 & 0.1429 & 0.1429 & 0.1429 & 0.1429 & 0.1463 & 0.1333 & 0.1429 & 0.1429 & 0.1429 & 0.1429 \\
\hline FLOWRATE & 3 & 0.0714 & 0.0714 & 0.0714 & 0.0714 & 0.0732 & 0.0667 & 0.0714 & 0.0714 & 0.0714 & 0.0714 \\
\hline UNRECOVERY RATE & 2 & 0.0476 & 0.0476 & 0.0476 & 0.0476 & 0.0488 & 0.0444 & 0.0476 & 0.0476 & 0.0476 & 0.0476 \\
\hline & SUM & 1.0000 & 1.0000 & 1.0000 & 1.0000 & 1.0000 & 1.0000 & 1.0000 & 1.0000 & 1.0000 & 1.0000 \\
\hline
\end{tabular}

Source: Macro risk assessment Audit Analytic - Danamon Bank Internal Audit Unit as of 31 March 2017.

Table 7 - Weight Result of Risk Factor Priority Risk

\begin{tabular}{||c|r||}
\hline \hline & \multicolumn{2}{|c|}{ PRIORITY } \\
\hline VECTOR \\
\hline UNSECURED & 0.1423 \\
\hline TOPUP & 0.0948 \\
\hline NEW NOA & 0.0948 \\
\hline RESTRUCTURE & 0.0237 \\
\hline FID FLOWRATE & 0.2200 \\
\hline OS UNSEC PER TOT OS & 0.0924 \\
\hline LASTOS & 0.0711 \\
\hline NPLWO6M & 0.1423 \\
\hline FLOWRATE & 0.0711 \\
\hline UNRECOVERY RATE & 0.0474 \\
\hline & \\
\hline
\end{tabular}

Source: Macro risk assessment Audit Analytic - Danamon Bank Internal Audit Unit as of 31 March 2017.

Results of Sub-criteria Priority Vector. Normalization and vector priority of pair matrix between sub-criteria for Unsecured is $2 \times 2$ coordinated matrix formed from risk factor that support the criterion factor in criteria and result of normalization formation and vector of priority matrix can be seen in table below:

Table 8 - Normalization Matrix and Priority Vectors of Inter Unsecured Batches

\begin{tabular}{|c|c|c|c|c|}
\hline & & DPD30UNSEC & OSUNSECLAST1Y & \\
\hline & Weight & 3 & 2 & PRIORITY VECTOR \\
\hline DPD30_UNSEC & 3 & 0.6000 & 0.6000 & 0.6000 \\
\hline OSUNSECLAST1Y & 2 & 0.4000 & 0.4000 & 0.4000 \\
\hline & SUM & 1.0000 & 1.0000 & \\
\hline
\end{tabular}

Source: Macro risk assessment Audit Analytic - Danamon Bank's Internal Audit Unit as of 31 March 2017.

Results of Inter-branch Pair Matrix. The normalization matrix and the vector weight of the intermediate pair priority for FID are the 10x10 ordered matrix formed from the branch and the result of matrix formation can be seen in the table below.

Table 9 - Paired Normalization Matrix of FID Inter-branches

\begin{tabular}{|c|c|c|c|c|c|c|c|c|c|c|c|}
\hline & & Branch 1 & Branch 2 & Branch 3 & Branch 4 & Branch 5 & Branch 6 & Branch 7 & Branch 8 & Branch 9 & Branch 10 \\
\hline & Weight & 5 & 5 & 2 & 4 & 2 & 4 & 1 & 1 & 1 & 1 \\
\hline Branch 1 & 5 & 0.1923 & 0.1923 & 0.1923 & 0.1923 & 0.1923 & 0.1923 & 0.1923 & 0.1923 & 0.1923 & 0.1923 \\
\hline Branch 2 & 5 & 0.1923 & 0.1923 & 0.1923 & 0.1923 & 0.1923 & 0.1923 & 0.1923 & 0.1923 & 0.1923 & 0.1923 \\
\hline Branch 3 & 2 & 0.0769 & 0.0769 & 0.0769 & 0.0769 & 0.0769 & 0.0769 & 0.0769 & 0.0769 & 0.0769 & 0.0769 \\
\hline Branch 4 & 4 & 0.1538 & 0.1538 & 0.1538 & 0.1538 & 0.1538 & 0.1538 & 0.1538 & 0.1538 & 0.1538 & 0.1538 \\
\hline Branch 5 & 2 & 0.0769 & 0.0769 & 0.0769 & 0.0769 & 0.0769 & 0.0769 & 0.0769 & 0.0769 & 0.0769 & 0.0769 \\
\hline Branch 6- & 4 & 0.1538 & 0.1538 & 0.1538 & 0.1538 & 0.1538 & 0.1538 & 0.1538 & 0.1538 & 0.1538 & 0.1538 \\
\hline Branch 7 & 1 & 0.0385 & 0.0385 & 0.0385 & 0.0385 & 0.0385 & 0.0385 & 0.0385 & 0.0385 & 0.0385 & 0.0385 \\
\hline Branch 8 & 1 & 0.0385 & 0.0385 & 0.0385 & 0.0385 & 0.0385 & 0.0385 & 0.0385 & 0.0385 & 0.0385 & 0.0385 \\
\hline Branch 9 & 1 & 0.0385 & 0.0385 & 0.0385 & 0.0385 & 0.0385 & 0.0385 & 0.0385 & 0.0385 & 0.0385 & 0.0385 \\
\hline Branch 10 & 1 & 0.0385 & 0.0385 & 0.0385 & 0.0385 & 0.0385 & 0.0385 & 0.0385 & 0.0385 & 0.0385 & 0.0385 \\
\hline & SUM & 1.0000 & 1.0000 & 1.0000 & 1.0000 & 1.0000 & 1.0000 & 1.0000 & 1.0000 & 1.0000 & 1.0000 \\
\hline
\end{tabular}

Source: Macro risk assessment Audit Analytic - Danamon Bank Internal Audit Unit as of 31 March 2017. 
Table 10 - Matrix of Paired Priority Vector between FID Branches

\begin{tabular}{||l|r||}
\hline & \multicolumn{1}{|c|}{$\begin{array}{l}\text { PRIORITY } \\
\text { VECTOR }\end{array}$} \\
\hline Branch 1 & 0.1923 \\
\hline Branch 2 & 0.1923 \\
\hline Branch 3 & 0.0769 \\
\hline Branch 4 & 0.1538 \\
\hline Branch 5 & 0.0769 \\
\hline Branch 6 & 0.1538 \\
\hline Branch 7 & 0.0385 \\
\hline Branch 8 & 0.0385 \\
\hline Branch 9 & 0.0385 \\
\hline Branch 10 & 0.0385 \\
\hline \hline
\end{tabular}

Source: Macro risk assessment Audit Analytic - Danamon Bank Internal Audit Unit as of 31 March 2017.

Calculation of Consistency Ratio (CR). The Consistency Ratio (CR) of risk factors used in this study is $0.0601 \%$. It shows that the risk factors (elements) used have logical relationships and are ranked consistently according to logical criteria.

Ranking Assessment Results. Data processing yields priority weights that can determine the risk ranking of each branch. The results of AHP treatment show 2 branches that have high risk, 4 branches have medium risk, and 4 branches have low risk as shown in the table below.

Table 11 - Risk Ranking of Each Branch

\begin{tabular}{||l|r|r|r||}
\hline \hline & RANK & \multicolumn{1}{|l||}{$\begin{array}{l}\text { TOTAL OF } \\
\text { PRIORIY } \\
\text { VECTOR }\end{array}$} & $\begin{array}{l}\text { PCNT } \\
\text { PRIORITY } \\
\text { VECTOR }\end{array}$ \\
\hline Branch 1 & 10 & 0.1336 & 13.36 \\
\hline Branch 2 & 9 & 0.1306 & 13.06 \\
\hline Branch 3 & 8 & 0.1119 & 11.19 \\
\hline Branch 4 & 7 & 0.1021 & 10.21 \\
\hline Branch 5 & 6 & 0.0965 & 9.65 \\
\hline Branch 6 & 5 & 0.0947 & 9.47 \\
\hline Branch 7 & 4 & 0.0891 & 8.91 \\
\hline Branch 8 & 3 & 0.0878 & 8.78 \\
\hline Branch 9 & 2 & 0.0819 & 8.19 \\
\hline Branch 10 & 1 & 0.0719 & 7.19 \\
\hline
\end{tabular}

Source: Macro risk assessment Audit Analytic - Danamon Bank Internal Audit Unit as of 31 March 2017.

The risk ranking scores used are divided or classified into 3 levels. The results of data processing show the minimum value of $7.19 \%$, the maximum value of $13.36 \%$. and 3 levels that have a distance scale of $2.06 \%$ can be seen in below.

Table 12 - Ranking Risk Scoring

\begin{tabular}{||r|r||}
\hline Max : & 13.36 \\
\hline Min : & 7.19 \\
\hline Range : & 2.06 \\
\hline Low : & $7.19-9.25$ \\
\hline Medium : & $9.26-11.30$ \\
\hline High : & $11.31-13.36$ \\
\hline
\end{tabular}

Source: Macro risk assessment Audit Analytic - Danamon Bank Internal Audit Unit as of 31 March 2017. 


\section{CONCLUSION}

Risk assessment on the branch of micro banking in audit planning is very effective because the assessment process is quite short with the level of accuracy which is optimal. Risk assessment in this study i conducted by measuring risk level values based on a multicriteria AHP method that can describe the level of risk in each branch. Risk assessment is based on the type of risk then used as the criterion of the AHP model. The processing results from 100 sample data using AHP, it is obtained 10 branches that have high risk, 56 branches that have medium risk, and 34 branches that have low risk. After the risk assessment results for each branch have been determined, then the Auditor can perform the audit planning. For branches with high and medium risk, the Auditor must audit every year. For low-risk branches, the Auditor may perform several samples to exercise control and every four years, the Auditor must audit it.

\section{REFERENCES}

1. Arens, A. A., Elder, R. J., \& Mark, B. (2012). Auditing and assurance services: an integrated approach. Boston: Prentice Hall.

2. Buana, A. (2009). Analisis Pengaruh Risk Assessment Terhadap Rating Audit Studi Pada Bank "X" (Doctoral dissertation, Program Pascasarjana Universitas Diponegoro).

3. Koutoupis, A. G., \& Tsamis, A. (2009). Risk based internal auditing within Greek banks: a case study approach. Journal of Management \& Governance, 13(1-2), 101-130.

4. Mulyadi. (2002). Auditing, Buku Dua, Edisi Ke Enam. Jakarta: Salemba Empat.

5. Saaty, T. L. (2013). Analytic hierarchy process. In Encyclopedia of operations research and management science (pp. 52-64). Springer US.

6. Saaty.TL., (2000), The Fundamentals of Decision Making and Priority Theory with the Analytic Hierarchy Process Thomas L. Saaty Vol. VI of the AHP Series, , 478 pp., RWS Publ., 2000 Sawyer, 2005.

7. Stulz, R. M. (1996). Rethinking risk management. Journal of applied corporate finance, 9(3), 8-25.

8. Supono, A. Y. (2007). Audit Berpeduli Risiko, BPKP (Pusat Pendidikan dan Pelatihan, Pengawasan Badan Pengawasan Keuangan dan Pembangunan) edisi keempat.

9. The Institute of Internal Auditors. (1991). Statement on Internal Auditing Standards (SIAS) no.9: Risk Assessment. 249 Maitland Avenue, Altamonte Springs, Florida. 